\title{
RESEARCH INTO THE CAUSES OF OVERHEATING OF BEARINGS AND SOLVING THE PROBLEM OF FURTHER OPERATION OF A 450 kVA SHORT BREAK DIESEL-GENERATING SET AT BELGRADE AIRPORT
}

\author{
Nikola P. Žegarac \\ Serbian Academy of Inventors and Scientists, Belgrade, \\ Republic of Serbia \\ e-mail: zegaracnikola@vektor.net \\ ORCID iD: @http://orcid.org/0000-0002-1766-8184
}

DOI: $10.5937 /$ vojtehg64-9568

\begin{abstract}
FIELD: Machine Engineering, Electrical Engineering ARTICLE TYPE: Original Scientific Paper ARTICLE LANGUAGE: English

\section{Abstract:}

The paper presents the research into the causes of increased heating in bearings and troubleshooting further exploitation of a Short Break diesel generating set with a power of 450 kVA at Belgrade Airport. The diesel engine is a type of Short Break, which means that in the event of an interruption in the electricity supply from the city network, there is a certain interruption of about 40 seconds until diesel generators start to supply electricity to the equipment and systems at Belgrade Airport. The main function of the diesel engine is to serve as a backup source power supply for devices and systems in case of limited visibility (lighting around the runway and many other devices and systems).

Key words: diesel generating set, elevated warming in bearings, measurement and analysis of vibration, vibration levels, vibrodiagnostics, vibration parameters, technical correctness of diesel generators .

\section{Introduction}

The paper presents research into the causes of increased warming of bearings as well as the solution for continuing the exploitation of a $450 \mathrm{kVA}$ Short Break diesel generating set at Belgrade Airport. 
This diesel engine is of a Short Break type, which means that in the event of an interruption in the electricity supply from the mains, there is some interruption of 40 seconds until powering devices and systems start using diesel generators.

The main function of the diesel generator is to serve as a backup power supply for devices and systems in conditions of limited visibility at Belgrade Airport (lighting around the runway and many other devices and systems), in order to increase air traffic safety.

\section{Description of the unit and the measuring points on the 450 kVA Short-Break diesel-electro generating set}

A Short-Break generating set is presented in Fig.1 (Technical documentation for Short Break generating sets, 1974). The diesel generator elements were mounted on a frame, i.e. a chassis of the electric generator: a diesel engine and a flywheel connected with a diesel engine by means of an MBM 500 electromagnetic coupling (see Fig. 2) of the German manufacturer Stromag (Technical documentation for electromagnetic couplings, Stromag, 1973), (Flender Betriebsanleitung BA 3100 DE 07.03 für Hochealastiche Kupplung, Bocholt, Deutschland, 2003).

The generator and the electric motor are connected to the generator flywheel with rubber flexible couplings, the German manufacturer Vulkan (Technical documentation for flexible couplings, Vulkan, 1973).

The electromotor drives the generator through the belt transmission. In case of deterioration of visibility conditions for aircraft landing at Belgrade Airport, staff on duty put the power generator into operation, even if there is no interruption in the electricity supply from the city power grid. This is a security measure for safe air traffic.

The electric motor drives the generator and the generator flywheel. Power devices and systems continue to be supplied from the city power grid. In the event of power interruption from the city grid, the diesel engine is immediately put into operation over an electromagnetic coupling and it provides further functioning of the power set. In this case, all the devices and systems are supplied with electricity from the generator unit.

The diesel generating set is from the German production company MWM - Germany Motoren Werke Mannheim, (Technical documentation for diesel engines, MWM, 1973).

During the work of the diesel engine, the problem of increased warming of flywheel bearings occurred, endangering the further exploitation of the generating sets.

Many of these phenomena can be detected with a vibrodiagnostic analysis of the unit. 


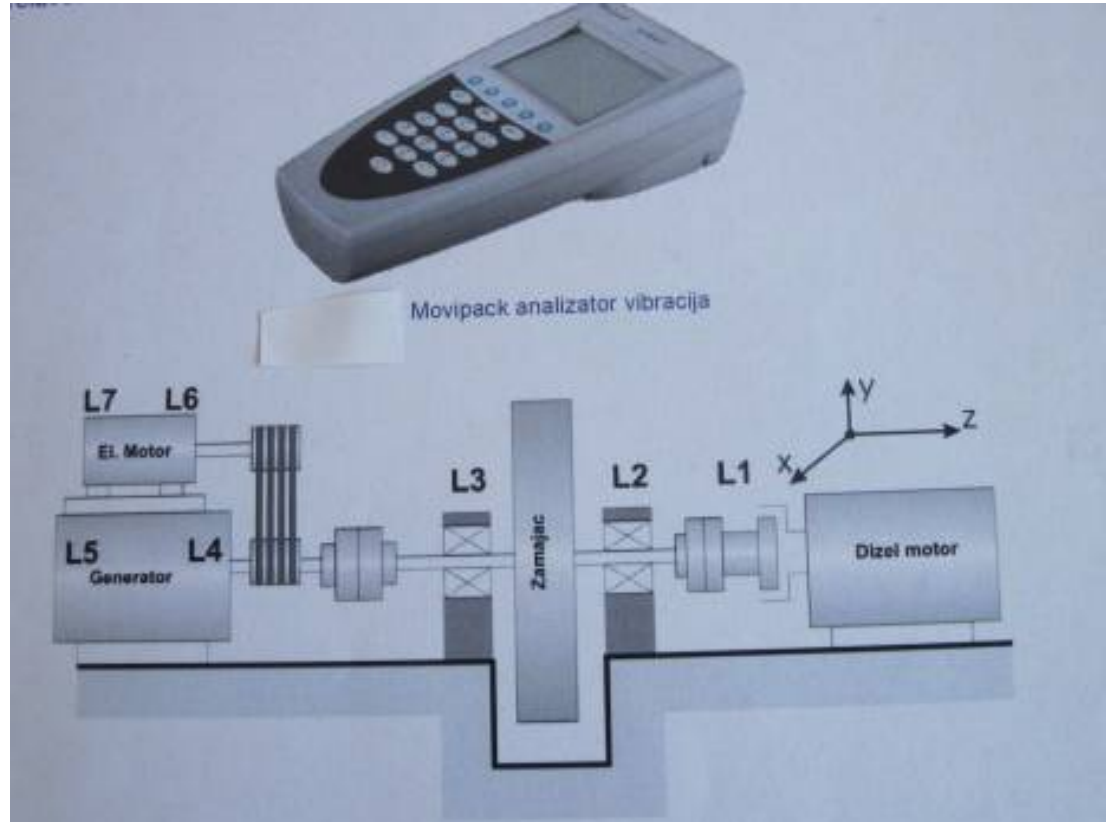

Figure 1 - Schematic presentation of the unit and the measuring points on the $450 \mathrm{kVA}$ Short-Break diesel-electric generator

Puc. 1 - Схема электростанции и расположение измерительных точек на дизельной электростанции типа Short-Break, с мощностью 450 кВА

Slika 1 - Šema postrojenja i merna mesta na dizel-elektroagregatu tipa Short-Break, snage $450 \mathrm{kVA}$

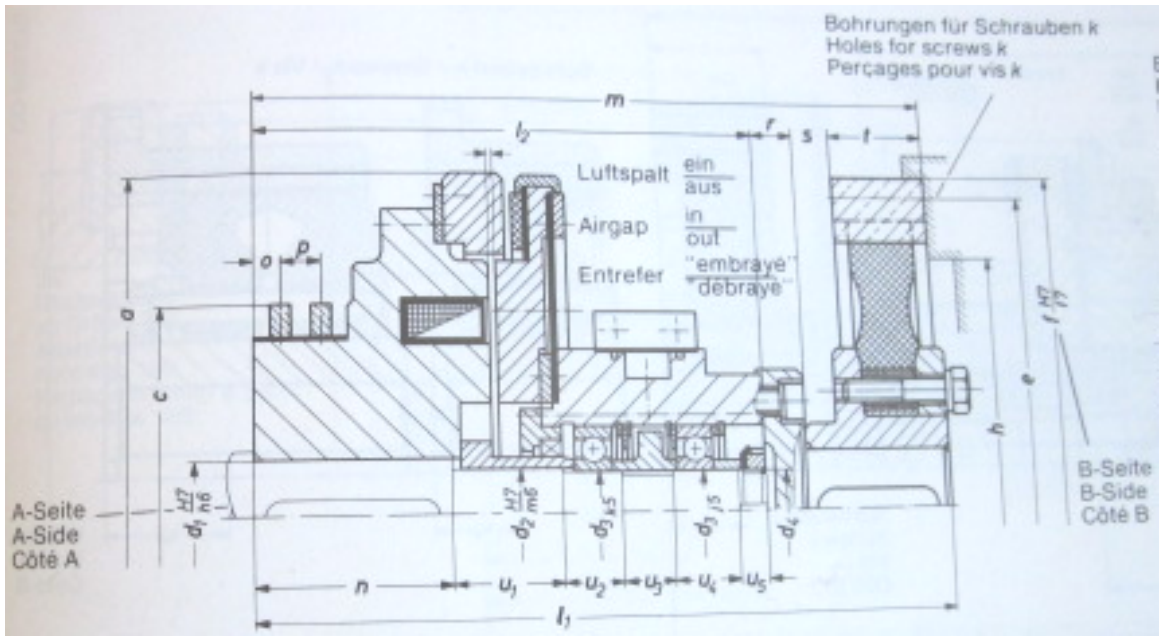

Figure 2 - Electromagnetic coupling of the German manufacturer Stromag, MBM 500 type Puc. 2 - Электромагнитная муфта немецкого производителя Stromag, MBM 500 type Slika 2 - Elektromagnetna spojnica nemačkog proizvođača Stromag tip MBM 500 


\section{Description of the measuring equipment, measurement points and recorded values}

This document is a detailed plan for vibrodiagnostic measurements and a subsequent analysis. We performed the measurements in the mode of the electric motor drive and in the diesel engine drive mode (Žegarac, 2010).

The description of the measuring chain:

- dual channel portable vibration analyzer MOVIPACK, Premium, French manufacturer, $01 \mathrm{~dB}$ (Figure 1),

- piezoelectric accelerometers with integrated electronics (ICP): ASH201, French manufacturer ,01 dB, and SA6200, US manufacturer Metrix,

- for recording generator speed: Movipack contactless integrated laser speed sensor,

- for measuring bearing temperatures: Movipack integrated noncontact laser pyrometer,

- for the post-processing of the results: Vibrograph Premium software, French manufacturer $01 \mathrm{~dB}$.

The vibrations were measured on all seven bearings in all three coordinate directions. The vibration measurements included recording of the following values:

1. First RMS value of vibration velocity expressed in $\mathrm{mm} / \mathrm{s}$. Taking such defined summary vibrations is prescribed by reference standard ISO 10816, which also prescribes the limits of permissible vibration levels for a given machine (Ličen, 2003). RMS- Root Mean Square - value.

2. Kurtosis second factor: the scalar factor that directly shows the degree of damage to rolling bearings, defined in such a way that its value does not depend on the speed and load of a machine. points).

3. Time display of vibrations (frequency range up to $10 \mathrm{kHz}, 16,383$

4. Frequency display of vibrations (frequency domain to $1 \mathrm{kHz}$, 3,200 frequency lines) as follows:

- The FFT frequency spectrum with amplitudes expressed by the RMS value of vibration velocity in $\mathrm{mm} / \mathrm{s}$.

- On the bearings, the cross-spectra of vibrations were recorded in two orthogonal radial directions.

- In the adjoining bearings, the cross-spectra of axial vibrations were recorded.

5. Measurement of the generator speed.

6 . Temperature of the generator bearing housing. 


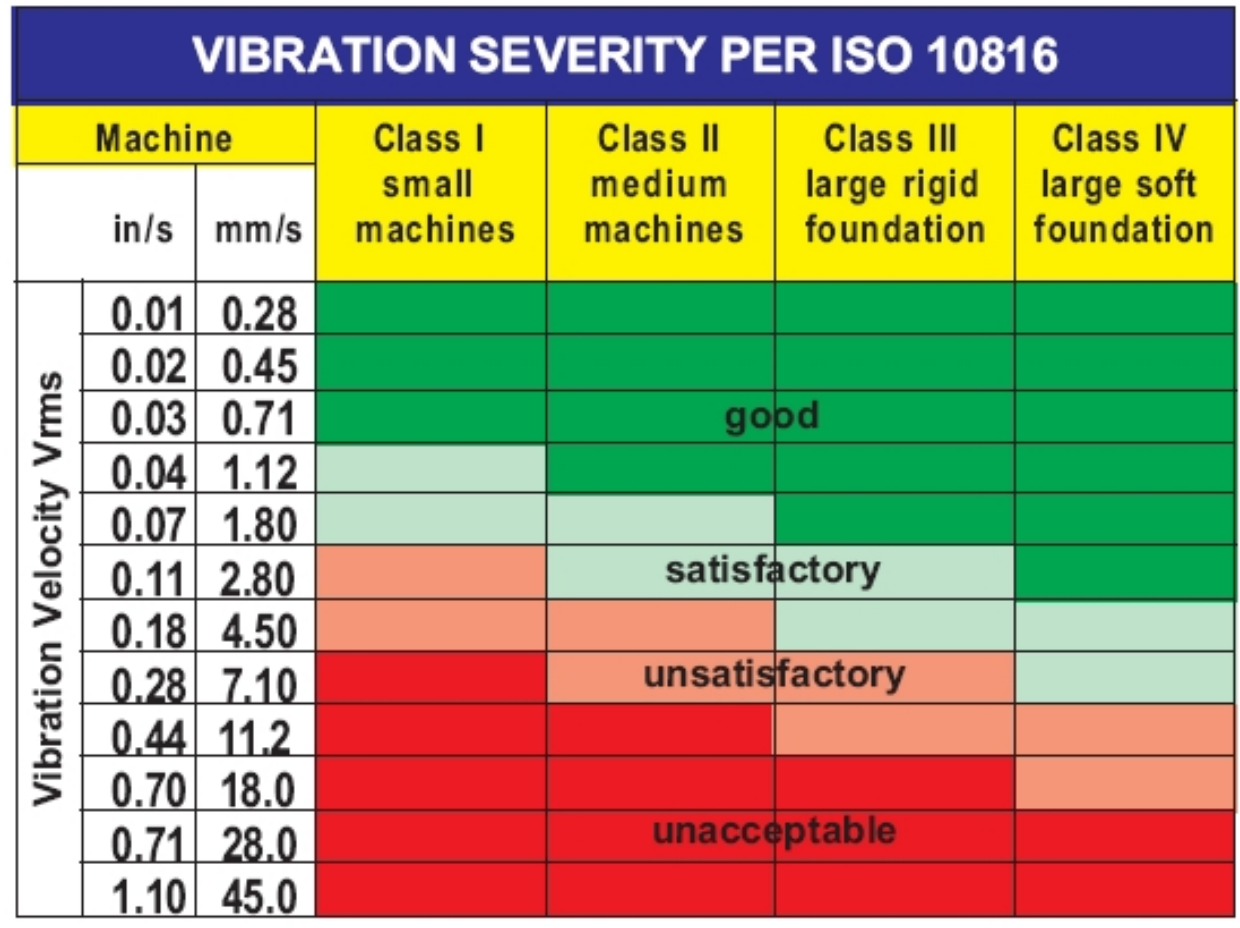

Figure 3-Recommendations for vibrations according to ISO 10816

Puc. 3 - Вибрационное состояние согласно стандарту ISO 10816 Slika 3 - Preporuke za vibracije po standardu ISO 10816

\section{Results of the measurements and their analysis}

Figures 1-4 give the graphical presentations of the frequency spectra of the recorded vibrations as well as their analysis in the directions $x, y$ and $z$, for the L1 bearing- electromagnetic coupling, for the L2 bearing - the flywheel side to the diesel engine, for the L3- bearing the flywheel side to the generator.

Because of this work extensiveness, the other results of the vibration measurements will be displayed only in tables (Žegarac, 2010). 


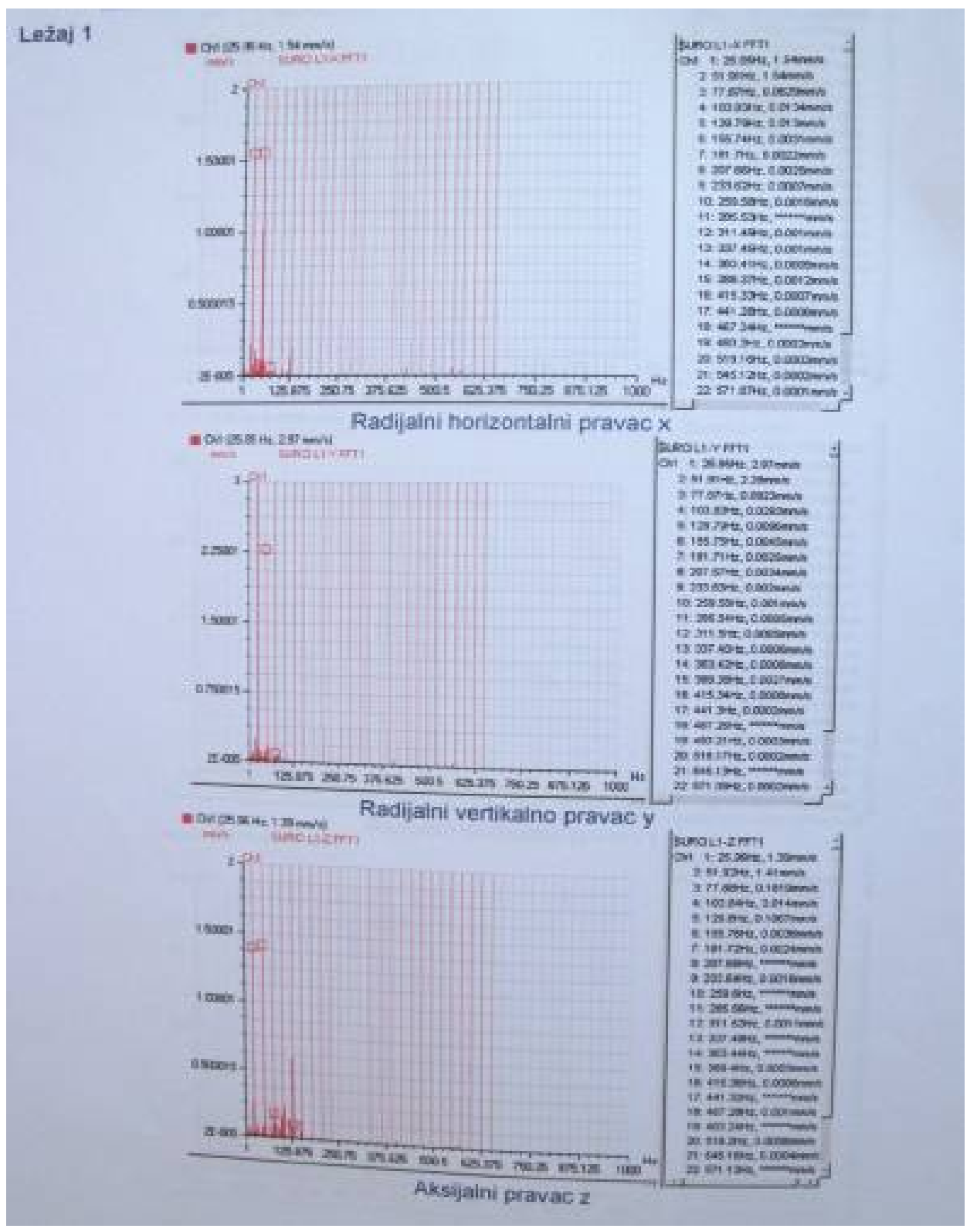

Figure 4 - Frequency spectrum of the recorded vibrations and their analysis for the $\mathrm{L} 1$ bearing

Puc. 4 - Спектр замеренных вибраций и анализ вибраций подшипника L1 Slika 4 - Frekventni spektar snimljenih vibracija i njihova analiza za ležaj L1 


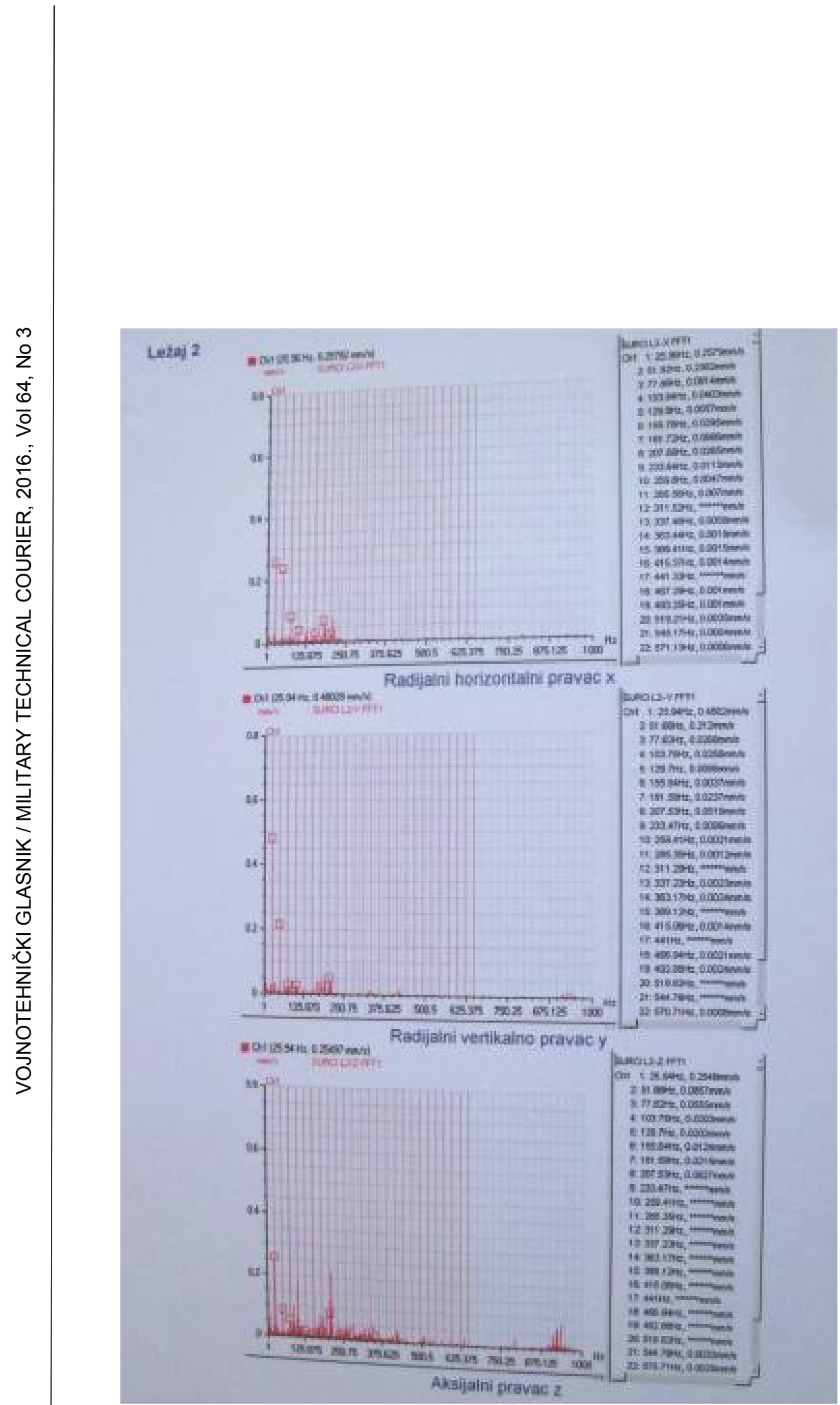

Figure 5 - Frequency spectrum of the recorded vibrations and their analysis for the L2 bearing

Puc. 5 - Спектр замеренных вибраций и анализ вибраций подшипника L2 Slika 5 - Frekventni spektar snimljenih vibracija i njihova analiza za ležaj L2 


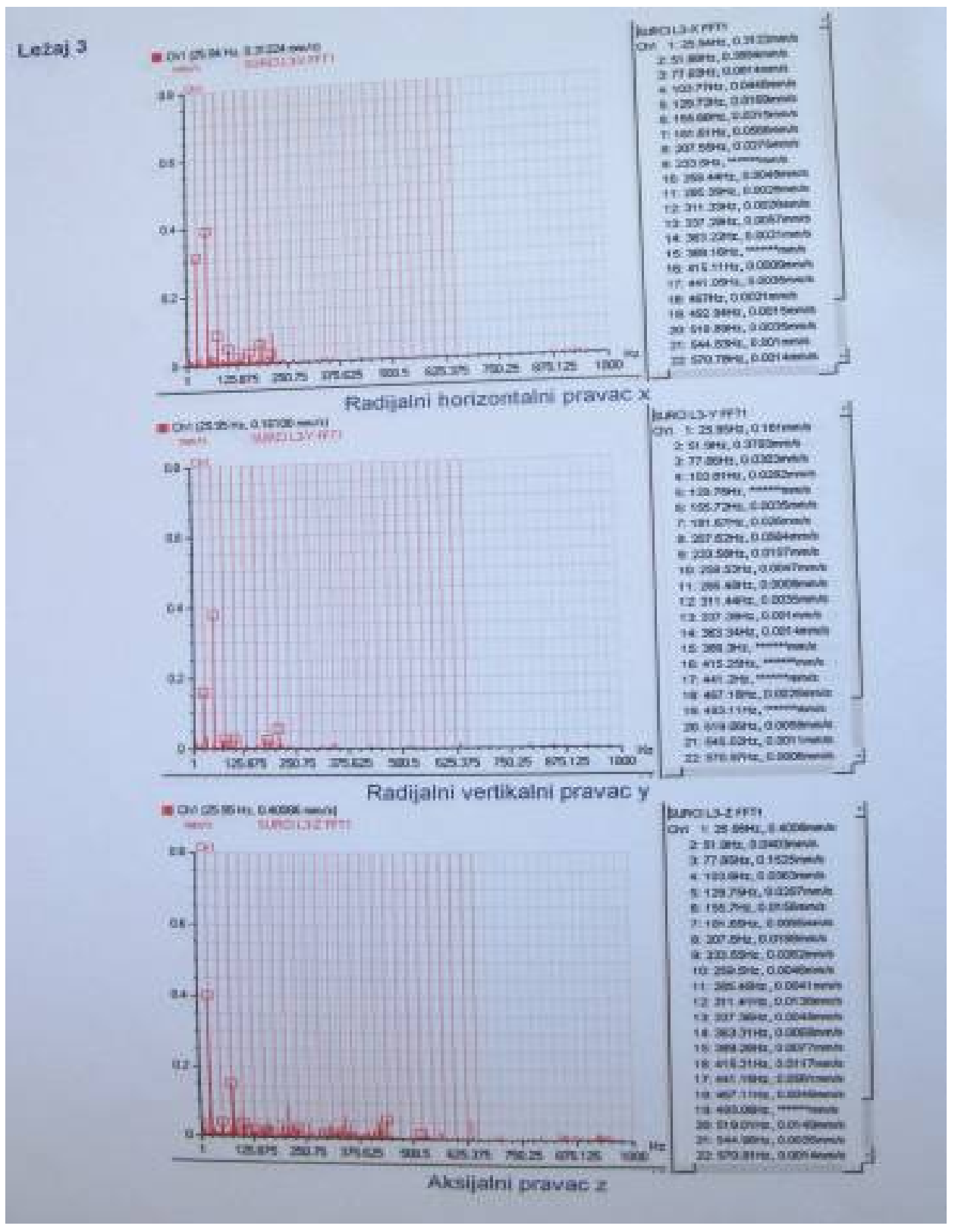

Figure 6 - Frequency spectrum of the recorded vibrations and their analysis of the $L 3$ bearing

Puc. 6 - Спектр замеренных вибраций и анализ вибраций подшипника L3

Slika 6 - Frekventni spektar snimljenih vibracija i njihova analiza za ležaj L3 
Table 1 presents the results of the measurements of the vibration scalar values:
Tabela 1 - Results of the measurements of the scalar values of vibrations Таблица 1 - Результаты измерений скалярных величин вибрации Tabela 1 - Prikazi rezultata merenja skalarnih veličina vibracija

\begin{tabular}{|c|c|c|c|c|c|c|c|c|c|}
\hline & \multicolumn{2}{|c|}{ Horizontal $x$} & \multicolumn{2}{|c|}{ Vertical y } & \multicolumn{2}{|c|}{ Axial z } & \multirow{2}{*}{$\begin{array}{c}\text { Assessment } \\
\text { by ISO } \\
10816\end{array}$} & \multirow[t]{2}{*}{ Bearing condition } & \multirow{2}{*}{$\begin{array}{c}\text { Temperature } \\
{ }^{\circ} \mathrm{C}\end{array}$} \\
\hline & $\begin{array}{l}R M S \\
\mathrm{~mm} / \mathrm{s}\end{array}$ & Kurt & $\begin{array}{l}R M S \\
\mathrm{~mm} / \mathrm{s}\end{array}$ & Kurt & $\begin{array}{l}R M S \\
\mathrm{~mm} / \mathrm{s}\end{array}$ & Kurt & & & \\
\hline$L 1$ & 2.34 & 2.96 & 3.84 & 2.94 & 2.22 & 3.19 & Acceptable & Satisfactory & 56 \\
\hline$\angle 2$ & 0.743 & 3.11 & 1.02 & 3.21 & 0.772 & 3.08 & Good & Satisfactory & 79 \\
\hline$\overline{L 3}$ & 0.996 & 2.98 & 0.974 & 3.36 & 0.782 & 7.57 & Good & Satisfactory & 76 \\
\hline L4 & 0.659 & 3.03 & 0.688 & 3.11 & 1.3 & 3.05 & Good & Satisfactory & - \\
\hline$\angle 5$ & 0.709 & 3.44 & 2.3 & 2.85 & 1.85 & 2.96 & Good & Satisfactory & - \\
\hline$\overline{L 6}$ & 1.58 & 3.17 & 2.83 & 2.88 & 3.53 & 4.09 & Acceptable & Satisfactory & - \\
\hline$L 7$ & 1.51 & 3.11 & 2.08 & 3.04 & 4.73 & 3.56 & Acceptable & Satisfactory & - \\
\hline
\end{tabular}

According to ISO standard 10816-3, the test of this machine belongs to class 4 , with the following levels and areas of tolerance limits of vibrations:

$<2.8 \mathrm{~mm} / \mathrm{s} \rightarrow$ GOOD

$<7.1 \mathrm{~mm} / \mathrm{s} \rightarrow$ acceptable

$<18 \mathrm{~mm} / \mathrm{s} \rightarrow$ ONLY ACCEPTABLE

$>18 \mathrm{~mm} / \mathrm{s} \rightarrow$ unauthorized

In the same way, the measurements were performed in the mode of the diesel engine drive.

\section{Conclusion}

Based on the summary levels of vibrations in accordance with ISO standard 10816, the condition of this machine can be assessed as satisfactory.

The vibrations on the bearings in the diesel engine drive mode did not significantly change. However, the temperature of the $L 2$ bearing on the flywheel on the diesel engine side significantly increased to $96{ }^{\circ} \mathrm{C}$ and the $\mathrm{L} 3$ bearing had a temperature of $80^{\circ} \mathrm{C}$, which was a sign that the problem was in the generator flywheel bearings.

The permissible L2 bearing temperature, according to the technical documentation for the generator in the diesel engine drive mode, is $85^{\circ}$ C (Technical documentation for Short Break generating sets, German company MWM, 1974). 


\section{Troubleshooting further operation of diesel-generator sets}

It was concluded that the further exploitation of the generating set would be very risky. It was obvious that the main problem was in the bearings of the generating set flywheel. The next step was to open both flywheel bearing housings to visually inspect the bearings. It was noticed that both bearings had changed their colour. The outer and inner rings of both bearings had changed their colour into dark or black, as a result of bearing elevated temperatures. These bearings are self aligning (Germany Pendelrollenlager), spherical rollers, in double rows, with a brass cage for better heat dissipation (Hauptkatalog SKF GruppePendelrolenlager, pp.695-777, Sweeden, 2007).

Heat effects and color changes were more pronounced in the bearing on the side of the diesel engine, because it suffers greater impact dynamic loading when the diesel engine is switched into operation.

The user of the generating set had already thought of disassembling the elements, the electromagnetic coupling and the generator flywheel and of replacing the bearings in the coupling as well as the bearings on the flywheel and of replacing the flexible coupling (rubber elements) between the flywheel and the generator of the generating set, since it had not been done since 1974, when the unit was put into operation.

However, the main problem was related to the dismantling of the generating set elements. The problem was the height of the aggregate hall, which was only 2.9 meters. The hall was not equipped with a crane hoist. The user was trying to devise a system of lifting the elements using some scaffolding which were very heavy and could not be entered into the aggregate hall through the front door.

To solve the problem, the author of this paper came up with the idea to construct scaffolding for dismantling assemblies.

The system for dismantling the parts of generators is shown in Figure 7 (Žegarac, 2009).

The system consisted of a handheld device for lifting that is set in place, position (1) in the figure, and three-pronged scaffolding.

Each leg of the scaffolding consisted of two pipes, position (3), that could be pulled in and pulled out, (telescopic system) thus providing the required height for lifting assemblies. At the top of the scaffolding, the telescopic tubes were fastened to the star element, position (4).

After the determination of the required height for lifting assemblies, the pipes were fixed with cross pins, position (2). In order to avoid slipping of the pipes on the concrete floor, holes were drilled in the floor of the aggregate hall and equipped with metal profiles, position (5), $\varnothing 10$ $\mathrm{mm}$ in diameter. One part of the metal profile enters the concrete floor 
and the other part goes into the metal pipe. In this way, the pipes were prevented from slipping on the concrete floor during lifting.

The assemblies were lifted using a hoist tied to a metal ring on the top of the scaffolding where three pipes were connected. The mass of the generator flywheel is $900 \mathrm{~kg}$.

When the generator flywheel was lifted to a certain height, it was rotated for $90^{\circ}$ and lowered onto the unit chassis. After that, the electromagnetic coupling, weighing $600 \mathrm{~kg}$, was dismantled.

Both bearings on the flywheel were replaced as well as the bearings in the electromagnetic coupling.

Slight traces of wear and tear were noticed on the internal and external rings of both bearings.

The thermal effect of overheating was very pronounced. The good thing was that the cages were made of brass, so they had better properties of heat dissipation and cooling. If the cages had been made of steel, accidents cannot have been avoided.

We had such an experience with the aggregate at Airport Tivat in Montenegro (Žegarac, Ličen, Zuber, 2000).
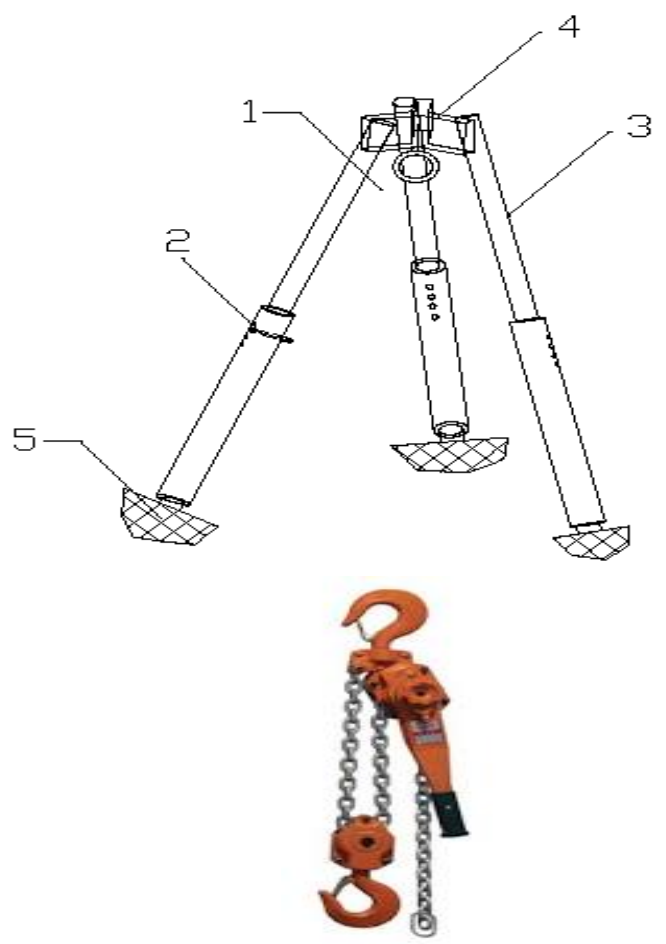

Figure 7 - The system for dismantling the power unit assembly Puc. 7 - Изображение системы для разборки узла агрегата Slika 7 - Prikaz sistema za demontažu sklopova agregata 


\section{What was a problem with these bearings?}

Flywheel bearings are lubricated with grease of certain gradation. On bearing housings, there is a system to extract excess grease by pistons and rods built in bearing housings. It often happens that the staff in charge, as soon as they hear some sound in the bearing, immediately lubricate it. They do not have enough knowledge in this field. It is important to know that, if a bearing is soaked in grease, it warms up, and, if there is not enough grease, friction occurs.

Different types of bearing grease were used, of various basic types and gradations. When the bearing is lubricated with some other grease type, chemical disintegration occurs and the lubricant properties are lost. Users need to know that oils and grease from different manufacturers should never be mixed, even when they have the same gradation. Each manufacturer of oil and grease adds its own additives that are different from those of other manufacturers.

The generator was moved back so that the rubber flexible coupling, Vulkan type, could be replaced. The flexible coupling consists of two plate-shape parts.

This flexible coupling had never been changed. It is known that rubber products are subject to aging and should be changed every 4 years, which was not the case here.

After the replacement, the elements were assembled and centered. The aggregate was again put into operation and tested in the electric motor drive mode and the diesel engine drive mode at maximum power. Vibrations and bearing temperatures were measured in the same places. The vibrations of the system were considerably lower than before replacing the bearings and other parts of the aggregate. The temperature of the bearing on the generator flywheel on the side to the diesel engine was $85^{\circ} \mathrm{C}$, and that of the flywheel bearing on the generator side was $76^{\circ} \mathrm{C}$. The values of vibration and temperature parameters matched the performance standards prescribed by the generator technical documentation.

In this way, the problem of research into the causes of elevated temperatures of generator bearings was successfully solved as well as the problem of further exploitation of the generator (Žegarac, Ličen, Zuber, 1999).

\section{Conclusion}

This paper presents a very useful example of research into the causes of increased warming of bearings and of the troubleshooting for further exploitation of the diesel generating set of Short-Break type at Belgrade Airport. Modern vibrodiagnostic methods were used for determining the technical condition of the unit. 
A very interesting system for lifting and dismantling generator elements was designed. It is a portable system that is assembled in an aggregate hall on site.

The main characteristic of this easily-usable system is a possibility of adjusting the height of lifting and dismantling parts of generators.

\section{References}

Flender Betriebsanleitung BA 3100 DE 07.03 für Hochelastische Kupplung, Bocholt,Deutschland, 2003.

Hauptkatalog SKF Gruppe- Pendelrolenlager, pp.695-777, Sweeden, 2007.

Ličen, H. 2003. Vibrodijagnostika kao elemenat osiguranja kvaliteta $i$ pouzdansoti. . U: Naučno-stručni skup sa međunarodnim učešćem, kvalitet, Zenica B\&H.

Standard, ISO 10816 Mechanical vibration of machines 1974.

Technical documentation for Short Break generating sets, MWM,1974.

Technical documentation for electromagnetic couplings, Stromag, 1973.

Technical documentation for flexible couplings, Vulkan, 1973.

Technical documentation for diesel engines, MWM, 1973.

Žegarac, N. 2009. Projektovanje sistema za demontažu sklopova na elektroagregatu tipa Short-Break, snage 450 kVA.Beograd: Aerodrom Beograd.

Žegarac, N. 2010.Izveštaj o merenju $i$ analizi vibracija na elektroagregatima tipa Short-Break.

Žegarac, N., Ličen, H., \& Zuber, N. 1999. Izveštaj o merenju i analizi vibracija na elektroagregatima tipa No-break, snage 100 kVA, u Radarskoj stanici, KovionaBeograd.Beograd.

Žegarac, N., Ličen, H., \& Zuber, N. 2000. Izveštaj o merenju i analizi vibracija na elektroagregatima tipa No-break, snage 30 kVA, Kontrola letenja Aerodrom Tivat.

ИССЛЕДОВАНИЕ ПРИЧИН ПЕРЕГРЕВА ПОДШИПНИКОВ

И РЕШЕНИЕ ПРОБЛЕМЫ ДАЛЬНЕЙШЕЙ ЭКСПЛУАТАЦИИ

ДИЗЕЛЬНОЙ ЭЛЕТРОСТАНЦИИ ТИПА SНОRТ ВRЕАК

МОЩНОСТЬЮ 450 КВА В ГП АЭРОПОРТ БЕЛГРАД

Никола П. Жегарац

Сербская академия изобретателей и ученых, Белград, Республика Сербия

ОБЛАСТЬ: машиностроение, электротехника

ВИД СТАТЬИ: оригинальная научная статья

ЯЗЫК СТАТЬИ: английский

Резюме:

В данной работе представлены исследования причин перегрева подшипников и решение проблемы дальнейшей эксплуатации дизельной электростанции типа Short Break мощностью 450 кВА в ГП Аэропорт Белград. 
Дизельная электростанция типа Short Break в случае перебоя электроснабжения от городских сетей останется без питания в течение 40 секунд, пока системные установки Аэропорта Белград не начнут заряжаться с помощью дизель-генераторов.

Дизель-генератор является резервным источником электропитания устройств и систем в условиях ограниченной видимости (освещение взлётно-посадочной полосы, рулёжной дорожки и пр.).

Ключевые слова: дизельные электростанции, перегрев подшипников, измерение и анализ вибраций, уровень вибраций, вибродиагностика, вибрационные параметры, техническое состояние дизельных электростанций.

ISTRAŽIVANJE UZROKA POVIŠENOG ZAGREVANJA LEŽAJEVA I REŠAVANJE PROBLEMA DALJE EKSPLOATACIJE DIZEL-ELEKTROAGREGATA TIPA SHORT BREAK, SNAGE 450 kVA, U JP AERODROM BEOGRAD

Nikola P. Žegarac

Srpska akademija izumitelja i naučnika, Beograd, Republika Srbija

OBLAST: mašinstvo, elektrotehnika

VRSTA ČLANKA: originalni naučni članak

JEZIK ČLANKA: engleski

\section{Rezime}

U radu su prikazana istraživanja uzroka povišenog zagrevanja ležajeva i rešavanje problema dalje eksploatacije dizel-elektroagregata tipa Short Break, snage 450 kVA, u JP Aerodrom Beograd.

Dizel-agregat je tipa Short Break, koji u slučaju prekida u napajanju električnom energijom iz gradske mreže, nakon oko 40 sekundi, počinje da napaja uređaje i sisteme na Aerodromu Beograd.

Osnovna funkcija dizel-agregata jeste da služi kao rezervni izvor napajanja uređaja i sistema u uslovima ograničene vidljivosti (rasveta oko piste i mnogi drugi uređaji i sistemi).

Ključne reči: dizel-elektroagregat, povišeno zagrevanje ležajeva, merenje $i$ analiza vibracija, nivoi vibracija, vibrodijagnostika, vibracioni parametri, tehnička ispravnost dizel-agregata.

Paper received on / Дата получения работы / Datum prijema članka: 21. 11. 2015.

Manuscript corrections submitted on / Дата получения исправленной версии работы / Datum dostavljanja ispravki rukopisa: 26. 03. 2016.

Paper accepted for publishing on / Дата окончательного согласования работы / Datum konačnog prihvatanja članka za objavljivanje: 28. 03. 2016. 
(C) 2016 The Author. Published by Vojnotehnički glasnik / Military Technical Courier

(www.vtg.mod.gov.rs, втг.мо.упр.срб). This article is an open access article distributed under the terms and conditions of the Creative Commons Attribution license

(http://creativecommons.org/licenses/by/3.0/rs/).

( 2016 Автор. Опубликовано в "Военно-технический вестник / Vojnotehnički glasnik / Military Technical Courier" (www.vtg.mod.gov.rs, втг.мо.упр.срб). Данная статья в открытом доступе и распространяется в соответствии с лицензией "Creative Commons"

(http://creativecommons.org/licenses/by/3.0/rs/).

(C) 2016 Autor. Objavio Vojnotehnički glasnik / Military Technical Courier (www.vtg.mod.gov.rs, втг.мо.упр.срб). Ovo je članak otvorenog pristupa i distribuira se u skladu sa Creative Commons licencom (http://creativecommons.org/licenses/by/3.0/rs/). 